160

Received: July 14, 2012

Accepted: November 22, 2012
Macedonian Journal of Animal Science, Vol. 3, No. 2, pp. 133-134 (2013)

In print ISSN $1857-6907$

On line ISSN $1857-7709$

UDC: 636.234 .083 .1

Professional paper

\title{
RELATIONSHIP BETWEEN THE METHOD OF MANURE REMOVAL AND SOME REPRODUCTIVE PROBLEMS IN HOLSTEIN COWS
}

\author{
Nurcan Karslioglu Kara ${ }^{1}$, Aşkın Galiç ${ }^{2}$ \\ ${ }^{1}$ Department of Animal Science, Faculty of Agriculture, Uludag University, Bursa, Turkey, \\ ${ }^{2}$ Department of Animal Science, Faculty of Agriculture, Akdeniz University, Antalya, Turkey \\ galic@akdeniz.edu.tr
}

\begin{abstract}
This study was carried out to determine the relationship between the method of manure removal and clinical mastitis, dystocia, retained placenta and repeated breeding, which are some of the main problems of cattle rearing. 709 cows that were examined, were housed in 37 dairy herds and for each cow the following data were collected: dystocia (yes/no), retained placenta (yes/no), clinical mastitis (yes/no) and repeated breeding (yes/no). 594 cows $(84 \%)$ were housed in the herds in which manure was removed manually, while the others had automatic manure scrapers. From the results, it was seen that prevalence of mastitis, dystocia and repeated breeding were dependent on the method of manure removal.
\end{abstract}

Key words: manure scraper; hygiene; reproductive problems; cattle

\section{ОДНОС ПОМЕЃУ НАЧИНОТ НА ОТСТРАНУВАЊЕ НА АРСКОТО ЃУБРИВО И НЕКОИ РЕПРОДУКТИВНИ ПРОБЛЕМИ КАЈ ХОЛШТАЈН КРАВИ}

\begin{abstract}
Студијата беше спроведена со цел да се утврди врската помеѓу начинот на отстранување на арското ѓубриво и клиничкиот маститис, дистоција (тешко породување), заостанувањето на плацентата и повторниот припуст, кои се некои од главните проблеми при одгледување на говедата. Беа прегледани вкупно 709 крави, сместени во вкупно 37 молзни стада, и за секоја крава беа собрани следните податоци: дистокија (да/не), задржана плацента (да/не), клинички маститис (да/не) и повторен припуст (да/не). 594 крави (84\%) беа сместени во стада во кои ѓубривото беше рачно отстранувано, додека пак другите имаа автоматски скрепери. Од резултатите, се покажа дека преваленцата на маститис, дистокија и повторниот припуст беа зависни од начинот на отстранување на арското ѓубриво.
\end{abstract}

Клучни зборови: скрепери за ѓубриво; хигиена; репродуктивни проблеми; говеда

\section{INTRODUCTION}

Environmental conditions must be comfortable to ensure the genetic potentials of dairy cows. The hygiene of cows is one of these conditions. For dairy cows, the cost of poor hygiene is an increased risk of mastitis and lameness (Cook 2002). Also, Schreiner and Ruegg (2003) showed a negative relationship between the cleanliness of the cows and the rate of subclinical mastitis. Constantly in contact with feces and urine of the legs and claws they become susceptible to infection and causes lameness in later stages (Vermunt and Greenough 1994). Likewise, Atasoy (2003) re- ported that the most important factors be prevent claw lesions and in later stage lameness are barn design and hygiene. Moreover, Atasever and Erdem (2009) reported that managemental factors related to a cow cleanness in dairy farms play an important role to obtain more milk especially in hot or rainy seasons and at the beginning or later lactation stages.

It has a positive effect on those relating to feet and legs, udder and reproductive problems, which are the three main problems in dairy cattle farming. Clean, dry and enough bedding material spread in stalls keeps cows clean and prevent the microbial activity. 
In this study, herds where manure was manually remove were compared with those ehere mechanical scrapers where used to determine any relationship between the method and some of the main problems.

\section{MATERIALS AND METHODS}

37 dairy herds in 3 center villages of Bursa (Osmangazi, Nilüfer, Mudanya) were visited during June 2009. All of the herds were members of the Cattle Breeders' Association. 594 out of 709 cows $(84 \%)$ were housed in the herds where manure was removed manually, while the others had automatic manure scrapers. The following data were collected for each cow: dystocia (yes/no), retained placenta (yes/no), clinical mastitis (yes / no) and repeated breeding (yes/no).

Prevalance of the problems was calculated and $t$ test was used to compare and determine the effect method of manure removal on dystocia, retained placenta, clinical mastitis or repeated breeding. Data were analyzed using SPSS 17.0 (Anonymous, 2008).

\section{RESULTS AND DISCUSSION}

Means and standard errors of prevalence of the problems are given in Table 1. According to the results of the breeders' account made in this study it has been shown that clinical mastitis $(\mathrm{P}<0.01)$, dystocia $(\mathrm{P}<0.05)$ and repeat breeding $(\mathrm{P}<0.01)$ have been affected by the method of manure removal. Manure can be removed more frequently in the herds where manure scrapers have not ben and. There must be a price associated with keeping animals; the price of poor hygiene is an increased risk of mastitis and some other problems for dairy cows.

Table 1

Determined prevalence of the problems, data in the table are means $\pm S E$

\begin{tabular}{lccc}
\hline \hline & \multicolumn{3}{c}{ Method of Manure removal } \\
Prevalance of problem, \% & Manually & Manure scrapers & P \\
\hline Clinical mastitis & $16.7 \pm 1.53$ & $10.4 \pm 2.86$ & 0.000 \\
Dystocia & $4.0 \pm 0.80$ & $1.7 \pm 1.22$ & 0.014 \\
Retained placenta & $5.9 \pm 0.97$ & $4.4 \pm 1.91$ & 0.184 \\
Repeated breeding & $24.2 \pm 1.76$ & $16.5 \pm 3.48$ & 0.000 \\
\hline \hline
\end{tabular}

\section{REFERENCES}

[1] Anonymous: SPSS for Windows, Release 17.0, 2008, SPSS Inc.

[2] Atasever, S., Erdem, H. (2009): Relationship between hygienic aspects and milk production characteristics of Holstein cows. Journal of Applied Animal Research, 35: $185-188$

[3] Atasoy, N. (2003): Erzurum yoresinde sut sigirlarinda gorulen ayak hastaliklarinin insidansi ve bunlarin sagaltimi. Yuzuncu Yil Universitesi Veteriner Fakultesi Dergisi, $14,1-5$

[4] Cook, N. B. (2002): The Influence of Barn Design on Dairy Cow Hygiene, Lameness and Udder Health, [editor unknown] 35th Annual Convention Proceedings American Association of Bovine Practitioners; 2002 Sep 26-28; Madison, WI. pp. 97-103.

[5] Schreiner, D. A., Ruegg, P. L. (2003): Relationship Between Udder and Leg Hygiene Scores and Subclinical Mastitis. Journal of Dairy Science, 86, 3460-3465,

[6] Vermunt, J. J., Greenough, P. R. (1994): Predisposing factors of laminitis in cattle. British Veterinary Journal, $150,151-164$. 